\title{
THE EFFECT OF THE OWNERSHIP AND THE GLOBAL CRISIS ON THE INCOME DIVERSIFICATION OF INDONESIAN BANKS
}

\author{
Murharsito $^{1}$
}

\begin{abstract}
This paper examines the effect of the ownership and the global crisis on income diversification of Indonesian Banks during the period of 2005 to 2012. We distinguish the income into traditional and non-traditional, where the latter is raised from non-traditional activities, such as service commission, trading revenue, insurance fee, etc. We also distinguish the types of ownership when applying the pooled estimation technique. The result shows the ownership does not affect the income diversification of Indonesian banks. Furthermore, public ownership affects the non-traditional incomes negatively, while foreign ownership effect is positive. This paper finds no evidence about the effect of the global crisis on income diversification of Indonesian banks.
\end{abstract}

Keywords: Income diversification, ownership, global crisis, Indonesian banks.

JEL Classification: G01, G15, G21

1 Lecturer at Nahdlatul Ulama' Islamic University (UNISNU) Jepara, email: murharsito@unisnu.ac.id. 


\section{INTRODUCTION}

The ownership structure of the banking sector in Indonesia diverse more, where the domination of state banks gradually decreases, and the private and the foreign banks play a greater role. By the end of 2002, the share of assets of the state banks comprises $46.44 \%$, while the private banks (both foreign exchange and non-foreign exchange) were $37.30 \%$, and the foreign and joint venture banks were $11.02 \%$. Ten years later in 2012, this composition shifted significantly; the asset of the state banks was 36.02 percent of the total bank, the private banks were $43.19 \%$, and the foreign and joint venture banks were $12.19 \%$, (Bank Indonesia, 2004, 2012).

Following the 1998 banking crisis, the government decided to launch privatization programs, which provided wide opportunity for foreign investors to participate in banking sector in Indonesia. The combination of bank branches, foreign joint banks and foreign owned private banks accounted for $31 \%$ of the total bank asset, jumped up from only $9 \%$ right before the crisis, (Sato, 2005). This condition has intensified the competition among banks and forces them, maximizing efforts to increase their market share.

For the banks, income diversification is one plausible strategy to improve profit. While keeping their traditional activities such as loan making, these banks can also engage in nontraditional activities, such as service commission, trading revenue, insurance fee, etc. In the case of Indonesian banking sector, the role of income diversification as one of the important income sources is evident (Sufian and Habibullah, 2010). Sufian and Habibullah found the income diversification has a positive relationship with the bank's profitability.

A further interesting issue is whether the ownership structure affects the income diversification of the banks. The different ownership structure may result in different performance. Several existing studies have revealed the significant effect of ownership on the bank's performance; most of them found the performance of the state owned enterprises were weaker relative to the other types of bank (Hart et.al., 1997; Shleifer and Vishny, 1997; Dewenter and Malatesta, 2001). Cornett et.al (2010) concluded that the state owned banks generate lower profit, not well capitalized and were more risky for allocating credit compared to the private banks.

A higher share of state owned banks exacerbates the bank concentration effect, while the presence of foreign banks prevents the effect of bank concentration on credit obstacles, (Beck et.al, 2004). In terms of efficiency, foreign owned banks are the most efficient, and in contrast, the state owned banks are the least efficient, (Bonin et.al, 2005). If the seconditions also apply in terms of bank's achievement in non-traditional income activities, there will be a difference in the non-interest income across the state, the private and the foreign banks. A recent study of the Indian banking industry by Pennathur et al (2012) indicate that different type of ownership will cause different impacts on income diversification, where the public sector banks earn the lowest fee income and the foreign banks able to generate higher fee income. 
On the other hand, the occurrence of financial crisis, which hit world economies more frequent, could also affect the bank's performance, particularly in their capability to generate the non-interest income. Recently, we witnessed two periods of a major crisis with severe impact; first is the 2008-2009 subprime mortgage crises and second are the 2012 Eurozone crisis. In contrast to the Asian Financial crisis, which was rooted from Southeast Asia, those two periods of crises were originated from advanced economies with pronounced impact for other region. Sufian and Habibullah (2010) concluded that the prior Asian Financial crisis negatively affects the bank's profitability in Indonesia.

The effect of the crisis to the bank's performance could be different according to their ownership structure. Cetoreli and Goldberg (2011) noted the foreign and the local banks play different role in transmitting the shocks of the crisis. The foreign banks channel the shocks by reducing their cross border lending. The foreign bank affiliations will also decrease its local lending, and the local banks have followed, reducing their loan since the interbank lending decline.

The objective of the study isto analyze the impact of the ownership and the crisis on the non-interest income of the banks. Beside the ownership, we also include several control variables in the model, including size, profitability, credit risk, lending, and bank's capitalization. Furthermore, this paper will also investigate the effect of the recent crisis, originated from advanced economies.

Pennathur et al (2012) classified the non-interest income to brokerage income and other non-interest income. In this paper, we follow De Young and Rice (2004) and De Young and Torna (2012), which categorize the non-interest income based on the characteristic of production and risk return, which potentially affect the probability of insolvency and financial distress. This leads us to three categories of the non-interest income; (i) non-traditional stakeholder activities, (ii) non-traditional fee for service, and (iii) traditional fee.

Non-traditional stakeholder activities are activities that require banks to hold risky asset, including investment banking, venture capital and proprietary trading. In contrast, the nontraditional fee for service activities does not require the banks to hold risky assets, for example, securities brokerage and insurance sales. The third category of the non-interest income (traditional fee activities) are the bank activities permitted prior to the deregulation i.e., fiduciary services and depositor services. In practice, due to data difficulties, we sum the last two categories (non-traditional fee for service and traditional fee). We argue both are similar in terms of their risk-return characteristic since they do not require the bank to hold risky assets.

The next section of this paper outlines the theory and related literatures. Section three present the data and methodology applied in this paper, while section four discusses the result and its analysis. Section five provides conclusions and will close the presentation of this paper. 


\section{THEORY}

\subsection{Selected Literature on Bank Ownership and Performance}

The bank ownership structure closely relates to privatization program. Bonin et.al (2005) analyzed the causality of the ownership, the privatization and the bank performance. He investigated the effect of bank privatization in European transition countries by analyzing the bank's income, the characteristic of their balance sheet, and their efficiency. Bonin et.al found the foreign owned banks scored highest efficiency, while the state owned banks are the least efficient. However, the local banks perform better in generating fee for a business service, since they have a local advantage relative to foreign banks. Furthermore, Bonin et.al found the method and the timing of privatization affected the bank's performance. The voucher privatization ${ }^{1}$ failed to improve the bank's efficiency, while an early stage privatization resulted in better performance of the bank.

The ownership also related to the financing constraint faced by the lender, Beck et.al (2004) found that the ownership structure of the bank coincides with the stages of economic development. Beck et.al argued the regulations and the characteristics of the country affect the relationship between the financing constraint andthe bank concentration. When the foreign banks exist, the institution of banking sector potentially develops, where the credit registration becomes more efficient. For this reason, the presence of foreign banks may dampen the effect of bank concentration on financing constraints. On the other hand, the greater the restriction on bank activities, the high government intervention, and the higher share of government ownership will exacerbate this effect.

lannotta et al (2007) compared the performance of public and private banks by controlling the bank characteristic. Even with lower cost, lannotta found the government owned banks produce lower profitability compared to the private banks. Government owned banks also have poorer quality of the loan and higher insolvency risk. The concentrated ownership does not affect the profitability of the banks. Furthermore, a concentrated ownership banks tend to have a better quality of the loan, lower asset, and lower insolvency risk.

Pennathur et al (2012) carried out a more specific analysis of the relationship between ownership and income diversification. They examined the effect of the ownership structure on the income diversification and the risk for Indian banks during the period of 2001 to 2009 . They found the ownership affect the non-interest income activities significantly, where the foreign banks generate higher fee income relative to public banks. Generally, the activity of public banks with higher government share is less intensive on generating the non-interest income. Pennathur et al also found the fee-based income reduces the default risk significantly.

1 Voucher privatization is a privatization method where citizens are given or can inexpensively buy a book of vouchers that represent potential shares in any state-owned company. This privatization method was mainly used in the early to mid-1990s in Russia, Bulgaria, Slovenia and Czechoslovakia, and in other transition economies of Central and Eastern Europe. 


\subsection{Selected Literature on Bank's Income Diversification}

De Young and Rice (2004) analyzed the relationship between the size and the technological advances in non-interest income. They found the non-interest income is larger as the size of the banks is larger, and a well-managed bank isless dependent on the non-interest income. Furthermore, some technological advances such as mutual fund and cashless transaction are associated with non-interest income increases, while the other types of technological advance such as loan securitization are linked with the non-interest income reduction. De Young and Rice argued a marginal increase of the non-interest income resulted in higher profit.

Acharya et al (2006) analyzed the bank's decision either to focus or to diversify their activities, and its effect on their return and risk. Using data from 105 Italian banksduring the period from 1993 to 1999, they found diseconomies in the diversification activities when the banks expand to industry with higher competition, particularly when the bank record no prior experience in this industry. The source of diseconomies was the deterioration of loan quality and the fall in bank returns.

Demirguc-Kunt and Huizinga (2010) analyze the impact of the bank activities and the short term funding strategy on the bank risk and return, using 1,334 banks in over 101 countries. They concluded that the diversification of the non-interest income activities increased the asset return, and significantly reduce the risk at very low level. In contrast, the non-deposit funding lower the asset return, though it also reduces the risk to the low level. Furthermore, banking strategies that rely on generating non-interest income or attracting non-deposit funding are very risky.

The research result on emerging countries also shows that the non-interest activities increased the bank's risk. Among others, Berger et.al (2010) examined the effect of the product and geographical focus, and the diversification strategies on 88 Chinese banks during 19962006; they found diseconomies of diversification in the loan, the deposit, the asset and the geographic dimension across those banks. On the opposite, a more focused bank can attain higher profit, lower cost, as well as higher efficiency.

\subsection{Selected Literature on the Income Diversification and the Crisis}

De Young and Tokna (2013) investigate whether the income from non-traditional banking activities contribute to the failures of commercial banks during the financial crisis. They found the asset-based non-traditional income increased the probability of bank failure, particularly for the banks already suffered from the financial crisis. The fee-based-non-traditional income had the opposite effect; it reduced the probability of bank failure during the crisis. This result confirmed the fundamental differences between the production and the characteristic of assetbased-non-traditional income versus the fee-based non-traditional income. 
Cornett et al (2010) explored and compared the ownership effect on bank performance during the crisis. He found that from the period of 1997 to 2000, the state banks deteriorated in cash flow returns, credit quality and capital core, more than the private banks. Prior to 2001, in countries with greater government involvement and greater political corruption in banking, the state owned banks significantly performed worse than the private banks, in terms of profitability, capitalization, and credit risk. After the crisis (2001-2004), this gap tapered.

Vallascas et al (2012) carried out a similar study by examining if the state bank diversification will improve the resiliency of the banks during the distress period. They found that bank, which diversified their income at a narrow level before the crisis, experienced performance declining during the financial crisis. In contrast, a broad diversified activity, for example, in lending and capital market, prevented the decline of bank performance during the crisis.

Inthe case of Indonesian banks, Sufian and Habibullah (2010) examined the determinants of bank's profitability during the Asian financial crisis. Using the data from 1990 to 2005, they found the income diversification and the capitalization positively associated to the profitability of the bank, while the overhead cost and the size negatively affected the bank's performance. These findings indicate the Indonesian banks to skimp their resources, particularly during the crisis and the pre-crisis period.

\section{METHODOLOGY}

\subsection{Data}

The data in this paper are obtained from the Bankscope. We analyze the commercial banks, including the state owned, the private national, and the private foreign banks. The state banks on this study only include the nationally owned bank and not the regional one. The foreign bank is the bank with major foreign shareholder, hence will include both subsidiaries of the foreign bank in Indonesia (for instance ANZ Indonesia Bank and HSBC Bank), and the private Indonesian banks which is owned by foreigner (for instance CIMB Niaga and Danamon Bank). We choose the cut point of $50.01 \%$ foreign ownership. The total sample comprises of 50 commercial banks, during the periods of 2005 to 2012.

The Bankscope database provides the income statement of banks in certain format, and broadly categorizes the income into the interest income and the non-interest income. The latter is further classified to six categories; they are (i) the net gain (losses) on trading and derivatives, (ii) the net gain (losses) on other securities, (iii) the net gain (losses) on assets at fair value through income statement, (iv) the net insurance income, (v) the net fee and commissions, and (vi) other operating income. 
We manage to match the above categories from the Bankscope with categorization made by De Young and Rice (2004)2. The first category of De Young and Rice (the non-traditional stakeholder activities), match the first two categories from the Bankscope, since they share similar implication for the bank to hold the risky asset. From now on, we term this category as "non-traditional-stakeholder".

As explained earlier, we combine the second and the third category of De Young and Rice (the non-traditional fee for service and traditional fee activities). The sum matches the net insurance income (category 4 of Bankscope) and net fee and commission (category 5). This is due to the net insurance income fit to the non-traditional fee for service, while the net fee and commission fitboth non-traditional fee for service and traditional fee activities. For now on, we term this category as "traditional and fee for service".

\subsection{Model}

This paper attempts to investigate the effect of the ownership and the global crisis on income diversification in Indonesian banking. To answer the research objectives, we use the following model developed by Pennathur et.al (2012):

$$
\begin{aligned}
& \text { Non-interestincome } e_{i t} \\
& =\alpha+\beta 1\left(\text { non }- \text { interest } \text { income }_{i t-1}\right) \\
& +\beta 2 \text { (Publicsectorbankdummy) } \\
& +\beta 3(\text { ForeignbankDummy })+\beta 4\left(L n T A_{i t}\right)+\beta 5\left(R O E_{i t}\right) \\
& +\beta 6\left(L L P_{i t}\right)+\beta 7\left(L / T A_{i t}\right)+\beta 8\left(\operatorname{Cap} / T A_{i t}\right) \\
& +\beta 9(\text { Crisisdummy })+\varepsilon_{i t}
\end{aligned}
$$

We use two proxies for our endogenous variable (non-interest income); first, the ratio of non-traditional stakeholder income to total non-interest operating income, and second, the ratio of traditional and fee for service income to total non-interest operating income. The ownership enters the model in the form of dummy. Control variables in this model are mostly based on Pennathur et.al (2012).

We proxy the size of the bank using total asset (in natural logarithm, LnTA); ROE for profitability; Loan Loss Provision (LLP) controlled by total loan for the loan quality; the ratio of loan to Total Asset (L/TA) for the growth of business; and using the ratio of capital to total asset (Cap/TA) as proxy for bank's capitalization. We also add the lagged of dependent variable to capture its persistency.

2 Three categories of non-interest income; (i) non-traditional stakeholder activities, (ii) non-traditional fee for service, and (iii) traditional fee. 
The measure the effect of the global crisis on income diversification, weset a dummy on the year when global crises occurred (2008 and 2009). Leaven and Valencia (2012) provided the database that includes all systemic banking, currency and sovereign debt crises, spanned from 1970 to 2011. This database conformed the year of 2008 and 2009 as years of crisis. In 2008 the banking crises occurred in Austria, Belgium, Iceland, Latvia, Luxembourg, Netherland, United Kingdom and United States, in 2009, the systemic banking crisis occurred in Denmark, Germany, Greece, Ireland, Mongolia and Ukraine.

In addition to these years, following Aizenman et al (2013), we also include 2012, when the sovereign debt crisis in Euro zone started and put downside risk to the global economy. We also note the growth rate of world economy were the lowest in 2008, 2009 and in 2012.

The first empirical model above internalizes the ownership in the form of dummy. A more plausible approach is to treat the ownership as cross section identifier. This will lead us to panel data estimation with three identifiers (state bank, foreign bank and private bank).

$$
\begin{aligned}
& \text { Non - interestincome }(\text { For each ownership type })_{i t}= \\
& \alpha+\beta 1 \text { Non }- \text { interestincome } \text { it }-1_{1}+\beta 2\left(\text { LnTA }_{i t}\right)+ \\
& \beta 3\left(R O E_{i t}\right)+\beta 4\left(L L P_{i t}\right)+\beta 5\left({\frac{L}{T A_{i t}}}_{i t}\right)+\beta 6\left(\frac{\text { Cap }}{T A}_{i t}\right)+ \\
& \beta 7(\text { Crisisdummy })+\varepsilon_{i t}
\end{aligned}
$$

\section{RESULT AND ANALYSIS}

\section{4..1. Ownership and Income Diversification}

We start the analysis by examining the impact of the ownership on the income diversification, and then analyze if there are differences in non-interest income across the banks. Based on the descriptive statistic, the mean value of non-traditional stakeholder income to total non-interest operating income for all samples is 16.08 percent, which is lower than the traditional and fee for service income to total non-interest operating income of 46.25 percent. This reveals that traditional and fee for service income is common non-interest income for Indonesian Banks. The complete result of descriptive statistic and correlation matrix is provided in Table 1.

We continue in examining the effect of ownership on the income diversification. We use pooled effect panel data with two considerations; first, because the ownership of the banks does not change over time, hence does not allow the fixed effect model. Second, using the Hausman test, the random effect model may not be used either. Pennathur et al (2012) also used the pooled effect panel estimation. The result of the estimation is provided in Table 2 . 


\begin{tabular}{|c|c|c|c|c|c|c|c|c|c|c|c|c|}
\hline \multicolumn{13}{|c|}{$\begin{array}{c}\text { Table } 1 . \\
\text { Descriptive Statistics and Correlation between Variables }\end{array}$} \\
\hline & MEAN & STD & NS & TFS & $\begin{array}{l}\text { LNAS } \\
\text { SET }\end{array}$ & ROE & $\begin{array}{l}\text { LLP } \\
\text { LOAN }\end{array}$ & $\begin{array}{l}\text { LOAN } \\
\text { ASSET }\end{array}$ & CAP_TA & PUBLIK & $\underset{\mathrm{N}}{\text { FOREIG }}$ & CRISIS \\
\hline NS & 0.160811 & 0.258980 & 1. 000000 & & & & & & & & & \\
\hline TFS & 0.462475 & 0.321136 & $-0.390203^{*}$ & 1. 000000 & & & & & & & & \\
\hline LNASSET & 9. 942848 & 2. 231431 & $-0.114244^{*}$ & $0.268656^{*}$ & 1. 000000 & & & & & & & \\
\hline ROE & 0.143538 & 0.342630 & -0.004310 & $0.154541^{*}$ & $0.289772^{\star}$ & 1.000000 & & & & & & \\
\hline LLPLOAN & 0.012300 & 0.110468 & 0.008166 & $0.119855^{\star}$ & 0.015212 & $0.787833^{*}$ & 1. 000000 & & & & & \\
\hline LOANASSET & 0.589038 & 0.136115 & $-0.069596^{*}$ & $0.095374^{*}$ & $-0.152637^{*}$ & $-0.079092^{*}$ & 0.033341 & 1. 000000 & & & & \\
\hline CAPASSET & 14. 40100 & 9.973828 & $0.160937^{*}$ & $-0.243321^{*}$ & $-0.358119^{*}$ & $-0.377536^{\star}$ & $-0.381904^{*}$ & -0.010389 & 1. 000000 & & & \\
\hline PUBLIC & 0.120000 & 0.325369 & $-0.068318^{*}$ & -0.023052 & $0.221172^{*}$ & -0.025561 & -0.011769 & -0.035176 & $0.135906^{*}$ & 1. 000000 & & \\
\hline FOREIGN & 0.480000 & 0.500226 & 0.058031 & -0.036343 & $-0.208244^{*}$ & -0.032200 & $-0.099907^{*}$ & $0.255132^{*}$ & $0.101896^{*}$ & $-0.504030^{*}$ & 1. 000000 & \\
\hline CRISIS & 0.375000 & 0.484729 & -0.002526 & $\left|0.121198^{*}\right|$ & 0.008474 & 0.034032 & $0.065928^{*}$ & $0.229213^{*}$ & -0.017192 & -0.044266 & 0.013042 & 1.000000 \\
\hline
\end{tabular}

Based on estimation result, the set of explanatory variables can better explain the traditional and fee for service ( $R^{2}$ is $38.57 \%$ and $39.72 \%$ for model 2 and model 4 ), than the non-traditional stakeholder ( $R^{2}$ is $20.58 \%$ and $21.70 \%$ for model 1 and model 3 ). The lagged of dependent variable performs effectively capture the effect of last year non-interest income, for all models the lagged of dependent variable is significantly affect dependent variable. This lag variable also prevents the case of first order serial correlation, indicated with the value of Durbin-Watson statistic of around 2.0.

We test the possibility of multicollinearity between the public and the foreign ownership, by running model 1 without public ownership and without foreign ownership interchangeably. The result shows no changes in the value of $\mathrm{R}^{2}$, indicating there is no multicollinearity between the public and the foreign ownership.

Model 1 and model 2 in Table 2 reveal that the ownership of the bank in Indonesia is not significant to explain the non-interest income, raised from non-traditional bank activities. However, the sign of estimated coefficient for the public ownership is negative (for both types of non-traditional incomes), while positive for foreign ownership. These expected signs (if significant) are in accordance with previous arguments that the performance of public banks is lower than the foreign banks (Bonin et al, 2005; lannotta et al, 2007; Pennathur et al, 2012).

Capitalization significantly affects the non-traditional stakeholder with positive sign. This means better capitalized bank can better generate the non-traditional non-interest income. The positive effect of capitalization is in line with the argument in Blum (1999) about the "leverage effect" of capital. This argument stated that the banks will maximize the value of its equity by investing in a more profitable, yet riskier activity. 
On the other hand, the profitability (ROE) has a positive and significant effect to traditional and fee for service (non-interest) income. Our estimate reflects that a one percent increase in ROE leads to $0.13 \%$ increase in traditional and fee for service non-interest income. Our result is contrary to De Young and Rice (2004), which found that the profitability negatively affected the non-interest income.

Table 3 provides the estimation result of some determinants of the non-interest income across ownership types. We estimate the model using pooled least square since the number of observation is small (the smallest number of observation is 30 and the largest is 145), which prevent us to use the fixed or the random effect model, beside the use of PLS possibly raise a small sample bias (Nickell, 1981).

\begin{tabular}{|c|c|c|c|c|}
\hline \multicolumn{5}{|c|}{$\begin{array}{c}\text { Table } 2 \\
\text { Effect of Ownership and Global Crisis to Income Diversification }\end{array}$} \\
\hline & Model 1 & Model 2 & Model 3 & Model 4 \\
\hline $\begin{array}{l}\text { Independent } \\
\text { Variables }\end{array}$ & $\begin{array}{l}\text { Nontraditional } \\
\text { Stakeholder }\end{array}$ & $\begin{array}{l}\text { Traditional and } \\
\text { Fee for Service }\end{array}$ & $\begin{array}{l}\text { Nontraditional } \\
\text { Stakeholder }\end{array}$ & $\begin{array}{l}\text { Traditional and } \\
\text { Fee for Service }\end{array}$ \\
\hline NS (lagged) & $\begin{array}{r}0.310934^{* * *} \\
(0.0000)\end{array}$ & - & $\begin{array}{r}0.304485^{* * *} \\
(0.0000)\end{array}$ & - \\
\hline TFS (lagged) & - & $\begin{array}{r}0.569372^{* * *} \\
(0.0000)\end{array}$ & - & $\begin{array}{r}0.56732^{* * *} \\
(0.0000)\end{array}$ \\
\hline Public & $\begin{array}{r}-0.041323 \\
(0.4565)\end{array}$ & $\begin{array}{r}-0.057759 \\
(0.2739)\end{array}$ & $\begin{array}{r}-0.042053 \\
(0.4468)\end{array}$ & $\begin{array}{r}-0.054802 \\
(0.2956)\end{array}$ \\
\hline Foreign & $\begin{array}{r}0.017752 \\
(0.6717)\end{array}$ & $\begin{array}{r}0.010146 \\
(0.782)\end{array}$ & $\begin{array}{r}0.016964 \\
(0.6843)\end{array}$ & $\begin{array}{r}0.013963 \\
(0.7016)\end{array}$ \\
\hline LnAsset & $\begin{array}{r}0.002613 \\
(0.8141)\end{array}$ & $\begin{array}{r}0.008279 \\
(0.3832)\end{array}$ & $\begin{array}{r}0.002251 \\
(0.8389)\end{array}$ & $\begin{array}{r}0.008622 \\
(0.3603)\end{array}$ \\
\hline ROE & $\begin{array}{r}0.031363 \\
(0.7053)\end{array}$ & $\begin{array}{r}0.13026^{* *} \\
(0.0335)\end{array}$ & $\begin{array}{r}0.033038 \\
(0.6892)\end{array}$ & $\begin{array}{r}0.125124^{* *} \\
(0.0397)\end{array}$ \\
\hline LLPLoan & $\begin{array}{r}0.058248 \\
(0.8171)\end{array}$ & $\begin{array}{r}-0.140973 \\
(0.4659)\end{array}$ & $\begin{array}{r}0.072418 \\
(0.773)\end{array}$ & $\begin{array}{r}-0.149157 \\
(0.437)\end{array}$ \\
\hline LoanAsset & $\begin{array}{r}-0.094784 \\
(0.5239)\end{array}$ & $\begin{array}{r}0.076194 \\
(0.5748)\end{array}$ & $\begin{array}{r}-0.078269 \\
(0.5981)\end{array}$ & $\begin{array}{r}0.044484 \\
(0.7427)\end{array}$ \\
\hline CapAsset & $\begin{array}{r}0.006844^{* * *} \\
(0.0058)\end{array}$ & $\begin{array}{r}0.000625 \\
(0.7762)\end{array}$ & $\begin{array}{r}0.006903^{* * *} \\
(0.0053)\end{array}$ & $\begin{array}{r}0.000603 \\
(0.7824)\end{array}$ \\
\hline Year & $\begin{array}{r}0.003315 \\
(0.7415)\end{array}$ & $\begin{array}{r}-0.009198 \\
(0.3134)\end{array}$ & $\begin{array}{r}0.006824 \\
(0.5066)\end{array}$ & $\begin{array}{r}-0.013804 \\
(0.1374)\end{array}$ \\
\hline Crisis & - & - & $\begin{array}{r}-0.053927 \\
(0.1298)\end{array}$ & $\begin{array}{r}0.074822^{* *} \\
(0.0248)\end{array}$ \\
\hline Constant & $\begin{array}{r}0.053364 \\
(0.7284)\end{array}$ & $\begin{array}{r}0.080375 \\
(0.5623)\end{array}$ & $\begin{array}{r}0.053713 \\
(0.7256)\end{array}$ & $\begin{array}{r}0.084898 \\
(0.5375)\end{array}$ \\
\hline
\end{tabular}




\begin{tabular}{|c|c|c|c|c|}
\hline \multicolumn{5}{|c|}{$\begin{array}{c}\text { Table } 2 \\
\text { Effect of Ownership and Global Crisis to Income Diversification (Continue) }\end{array}$} \\
\hline & Model 1 & Model 2 & Model 3 & Model 4 \\
\hline $\begin{array}{l}\text { Independent } \\
\text { Variables }\end{array}$ & $\begin{array}{l}\text { Nontraditional } \\
\text { Stakeholder }\end{array}$ & $\begin{array}{l}\text { Traditional and } \\
\text { Fee for Service }\end{array}$ & $\begin{array}{l}\text { Nontraditional } \\
\text { Stakeholder }\end{array}$ & $\begin{array}{l}\text { Traditional and } \\
\text { Fee for Service }\end{array}$ \\
\hline R squared & 0.2058 & 0.3857 & 0.2170 & 0.3972 \\
\hline F statistic & $\begin{array}{r}4.662936^{* * *} \\
(0.000017)\end{array}$ & $\begin{array}{r}18.62367^{* * *} \\
(0.000000)\end{array}$ & $\begin{array}{r}4.462642^{* * *} \\
(0.000015)\end{array}$ & $\begin{array}{r}17.52763^{* * *} \\
(0.000000)\end{array}$ \\
\hline Hausman & $\begin{array}{r}62.99388^{* * *} \\
(0.0000)\end{array}$ & $\begin{array}{r}52.926482^{* * *} \\
(0.0000)\end{array}$ & $\begin{array}{r}\text { 72. } 40831^{* * *} \\
(0.0000)\end{array}$ & $\begin{array}{r}51.713238^{* * *} \\
(0.0000)\end{array}$ \\
\hline Durbin Watson statistic & 1. 985027 & 2. 296834 & 1. 9821 & 2. 290361 \\
\hline $\mathrm{N}$ & 172 & 277 & 172 & 277 \\
\hline \multicolumn{5}{|c|}{$\begin{array}{l}\text { Note: NS= Nontraditional Stakeholder; TFS = Traditional and Fee for Service; Public= Public Sector Banks Dummy; } \\
\text { Foreign= Foreign Banks Dummy; LNASSET }=\text { Log of Total assets; ROE= Return on Equity; LLPLOAN=loan loss } \\
\text { provisions/Total loans; LOANASSET= Loans to Total Asset; Cap ta = Capital TO Total Asset; Year= year Dummy; Crisis= } \\
\text { Crisis Year Dummy. Absolute values of t-statistics are in parentheses, }{ }^{*},{ }^{\star}, \text { and }{ }^{* \star \star} \text { indicate significance at } 10 \%, 5 \%, \\
\text { and } 1 \% \text { levels respectively. }\end{array}$} \\
\hline
\end{tabular}

For public bank, the capitalization of the bank significantly affects the non-traditional stakeholder non-interest income with positive sign. This is in line with the estimation of nontraditional stakeholder for all of ownership sample.

For the state owned banks, the size significantly affect the traditional and fee for service, with positive sign. This means the bigger the state bank, the greater the earnings of traditional and fee for service they can generate. This finding is in line with Hidayat et al (2012), which argued the income diversification as the result of deregulation in Indonesia, is more associated with the large banks practice.

For the foreign banks, we found none of the explanatory variables has significant effect to their non-traditional (non-interest) income, except for the lagged of dependent variable. However, for traditional and fee for service (non-interest) income, the credit risk (proxied with the ratio of loan loss provision to total loan) has a positive and significant effect. Possible explanation for this result would be these foreign banks attempt to seek another income since lending activities faces quite significant risk. This finding is different with Pennathur et al (2012) which found a positive and significant effect of the credit risk effect on the fee-based income for private banks (not foreign banks).

The estimation result for the private banks is similar to the foreign banks. For this type of ownership, most independent variables are not significant to affect the non-traditional income, except for the lagged of dependent variable. When we look at the traditional and service fee income for these private banks, we find the profitability and the credit risk are significant predictors for their traditional and fee-based income. The effect of profitability is positive while the credit risk is negative as expected. A one percent increase in ROE leads to $0.25 \%$ increase in traditional and fee for service income. On the other hand, a one percent 
increase in the credit risk will reduce the traditional and fee for service income by $0.54 \%$ for the private banks. This result indicate the private banks engage well in generating both interest and non-interest income.

\begin{tabular}{|c|c|c|c|}
\hline \multicolumn{4}{|c|}{$\begin{array}{c}\text { Table } 3 \\
\text { Determinants of Income Diversification for Each Ownership Type }\end{array}$} \\
\hline Independent Variables & Public Bank & Foreign Bank & Private Bank \\
\hline \multicolumn{4}{|l|}{$\begin{array}{l}\text { Panel A dependent variable } \\
\text { is nontraditional stakeholder }\end{array}$} \\
\hline NS (lagged) & $\begin{array}{r}-0.158753 \\
(0.2664)\end{array}$ & $\begin{array}{r}0.54057^{* * *} \\
(0.0000)\end{array}$ & $\begin{array}{r}0.558315^{* * *} \\
(0.0000)\end{array}$ \\
\hline Ln Asset & $\begin{array}{r}-0.137273 \\
(0.3158)\end{array}$ & $\begin{array}{r}-0.002021 \\
(0.8815)\end{array}$ & $\begin{array}{r}-0.000785 \\
(0.9573)\end{array}$ \\
\hline ROE & $\begin{array}{r}1.490357 \\
(0.1685)\end{array}$ & $\begin{array}{r}0.020209 \\
(0.8241)\end{array}$ & $\begin{array}{r}0.248891^{\text {*** }} \\
(0.0012)\end{array}$ \\
\hline LLP Loan & $\begin{array}{r}7.257302 \\
(0.175)\end{array}$ & $\begin{array}{r}-0.550451 \\
(0.4016)\end{array}$ & $\begin{array}{r}-0.539426^{* *} \\
(0.0268)\end{array}$ \\
\hline Loan Asset & $\begin{array}{r}-1.415572 \\
(0.2115)\end{array}$ & $\begin{array}{r}-0.281913 \\
(0.1332)\end{array}$ & $\begin{array}{r}0.257583 \\
(0.2076)\end{array}$ \\
\hline Cap Asset & $\begin{array}{r}0.019745^{* *} \\
(0.0143)\end{array}$ & $\begin{array}{r}-0.000755 \\
(0.823)\end{array}$ & $\begin{array}{r}-0.003174 \\
(0.5317)\end{array}$ \\
\hline Year & $\begin{array}{r}0.048576 \\
(0.3746)\end{array}$ & $\begin{array}{r}0.005078 \\
(0.6771)\end{array}$ & $\begin{array}{r}-0.022576 \\
(0.1652)\end{array}$ \\
\hline Constant & $\begin{array}{r}1.724989 \\
(0.3507)\end{array}$ & $\begin{array}{r}0.294897 \\
(0.1387)\end{array}$ & $\begin{array}{l}0.17513 \\
(0.4207)\end{array}$ \\
\hline R squared & 0.4656 & 0.3549 & 0.4729 \\
\hline F statistic & $\begin{array}{l}2.737696^{* *} \\
(0.033277)\end{array}$ & $\begin{array}{r}6.443788^{* \star *} \\
(0.000005)\end{array}$ & $\begin{array}{r}10.63859^{* \star *} \\
(0.000000)\end{array}$ \\
\hline Hausman & - & $\begin{array}{r}32.966402^{* * *} \\
(0.0000)\end{array}$ & $\begin{array}{r}25.370487^{* * \star} \\
(0.0007)\end{array}$ \\
\hline Durbin Watson statistic & 2.31552 & 1. 949832 & 2. 089733 \\
\hline $\mathrm{N}$ & 30 & 90 & 91 \\
\hline $\begin{array}{l}\text { Panel B dependent variable } \\
\text { is traditional fee for service }\end{array}$ & & & \\
\hline TFS (lagged) & $\begin{array}{r}0.135024 \\
(0.485)\end{array}$ & $\begin{array}{r}0.659874^{* * *} \\
(0.0000)\end{array}$ & $\begin{array}{r}0.495356^{\star * *} \\
(0.0001)\end{array}$ \\
\hline Ln Asset & $\begin{array}{r}0.235416^{* *} \\
(0.0116)\end{array}$ & $\begin{array}{r}0.008416 \\
(0.4312)\end{array}$ & $\begin{array}{l}-0.00678 \\
(0.6912)\end{array}$ \\
\hline ROE & $\begin{array}{r}-1.458078 \\
(0.3032)\end{array}$ & $\begin{array}{r}-0.036124 \\
(0.6463)\end{array}$ & $\begin{array}{r}-0.208717 \\
(0.3841)\end{array}$ \\
\hline LLP Loan & $\begin{array}{r}-0.060938 \\
(0.9933)\end{array}$ & $\begin{array}{r}1.061116^{* *} \\
(0.0373)\end{array}$ & $\begin{array}{r}0.399327 \\
(0.5074)\end{array}$ \\
\hline
\end{tabular}




\begin{tabular}{|c|c|c|c|}
\hline \multicolumn{4}{|c|}{$\begin{array}{c}\text { Table } 3 \\
\text { Determinants of Income Diversification for Each Ownership Type (Continue) }\end{array}$} \\
\hline Independent Variables & Public Bank & Foreign Bank & Private Bank \\
\hline Loan Asset & $\begin{array}{r}0.981914 \\
(0.3427)\end{array}$ & $\begin{array}{r}-0.095103 \\
(0.5023)\end{array}$ & $\begin{array}{r}-0.139914 \\
(0.5646)\end{array}$ \\
\hline Cap Asset & $\begin{array}{r}0.006033 \\
(0.471)\end{array}$ & $\begin{array}{r}0.000955 \\
(0.6567)\end{array}$ & $\begin{array}{r}-0.004627 \\
(0.5617)\end{array}$ \\
\hline Year & $\begin{array}{r}-0.065639 \\
(0.1887)\end{array}$ & $\begin{array}{r}-0.003138 \\
(0.7021)\end{array}$ & $\begin{array}{r}0.009888 \\
(0.5976)\end{array}$ \\
\hline Constant & $\begin{array}{r}-2.470474 \\
(0.0379)\end{array}$ & $\begin{array}{r}0.128285 \\
(0.3912)\end{array}$ & $\begin{array}{r}0.257495 \\
(0.2668)\end{array}$ \\
\hline R squared & 0.411933 & 0.5155 & 0.4019 \\
\hline F statistic & $\begin{array}{r}3.302293^{* * *} \\
(0.00897)\end{array}$ & $\begin{array}{c}20.81987^{* * *} \\
(0.000000)\end{array}$ & $\begin{array}{r}\text { 4. } 224526^{* * *} \\
(0.001221)\end{array}$ \\
\hline Hausman & - & $\begin{array}{r}35.93624^{* \star *} \\
(0.0000)\end{array}$ & $\begin{array}{r}24.756586^{\star * *} \\
(0.0008)\end{array}$ \\
\hline Durbin Watson statistic & 2.189925 & 2. 066938 & 2. 155818 \\
\hline $\mathrm{N}$ & 41 & 145 & 52 \\
\hline
\end{tabular}

\subsection{The Global Crisis and The Income Diversification}

Model 3 in Table 2 provides the estimation result of the global crisis effect on the non-traditional stakeholder (non-interest) income, while model 4 provides the effect on the traditional and fee for service (non-interest) income. We notice two different results; for the non-traditional stakeholder, the effect of the crisis is negative and not significant, while for the traditional income, the coefficient is significant with positive sign.

Longstaff (2010) finds strong evidence the contagion of subprime crisis to the other financial market. He investigated the pricing of subprime asset backed collateralized debt obligations (CDOs), and found that the financial contagion to other markets is propagated through the liquidity and the risk premium channel. The negative effect of the global crisis is as expected (though not significant), since the non-interest income is commonly generated from risky activities. These activities depend highly on asset price within the financial markets, which is highly subject to the crisis. The positive effect of crisis to traditional and fee for service reveals that during the global crisis, the pressure of the crisis on bank's performance is later compensated by the effort of the bank to alter the negative effect using the other sources of income. 
Table 4 also provide the estimation result of the global crisis impact across bank's ownership, using pooled least square model. The global crisis does not affect the non-traditional income of the bank, with the negative sign. For the state banks, the effect is also not significant, but with a positive sign. While keeping that these coefficient are not statistically significant, a possible explanation of the opposite direction of the effect of the global crisis between the private and the foreign banks in one side, and the public bank on other side is because they have different sources of non-traditional (non-interest) income. It is possible that the assets hold by the private and the foreign banks are more exposed by the global crisis.

On traditional and fee for service (non-interest) income, the effect of the global crisis is significant with positive sign for foreign banks. It means during the crisis, the traditional and fee for service (non-interest) income of foreign banks increased. This finding is in line with Jeon and Miller (2005), who found a steady performance of foreign banks in Korea during the Asian Financial crisis, while on the other side the crisis deteriorated the domestic banks performance. Jeon and Miller argued that one of the reasons is because the foreign banks in Korea rely more on fee for service income rather than the lending interest income. Foreign banks in Indonesia share similar characterstic. Hadad et al (2004) concluded that the foreign banks in Indonesia were more focus on fee based income activities but less active in intermediation function. To conlude, the positive performance of foreign banks to generate the traditional and fee for service income during the global crisis, is possibly caused by their nature to specialize more in non-interest income.

\begin{tabular}{l|r|r|r}
\multicolumn{4}{|c}{ Table 4} \\
\multicolumn{3}{|c|}{ The Effect of the Crisis onthe Income Diversification across Bank's Ownership } \\
\multicolumn{1}{|c|}{ Independent Variables } & Public Bank & \multicolumn{1}{|c}{ Foreign Bank } & \multicolumn{1}{c}{ Private Bank } \\
Panel A dependent variable & & & \\
is nontraditional stakeholder & & & \\
\hline NS (lagged) & 0.152591 & $0.521513^{* * *}$ & $0.550921^{* * *}$ \\
& $(0.4372)$ & $(0.0000)$ & $(0.0000)$ \\
\hline Ln Asset & $0.223535^{* *}$ & -0.001633 & -0.000903 \\
& $(0.0186)$ & $(0.9040)$ & $(0.9507)$ \\
\hline ROE & -1.331828 & 0.018253 & $0.242838^{* * *}$ \\
& $(0.3533)$ & $(0.8406)$ & $(0.0015)$ \\
\hline LLP Loan & -1.397026 & -0.600388 & $-0.542397^{* *}$ \\
& $(0.8519)$ & $(0.8406)$ & $(0.0256)$ \\
\hline Loan Asset & 0.695519 & -0.272622 & 0.206692 \\
& $(0.5307)$ & $(0.1459)$ & $(0.3197)$ \\
\hline Cap Asset & 0.007084 & -0.000728 & -0.003031 \\
& $(0.4080)$ & $(0.8289)$ & $(0.5492)$ \\
\hline Year & -0.068284 & 0.008622 & -0.025462 \\
& $(0.1762)$ & $(0.4929)$ & $(0.121)$ \\
\hline
\end{tabular}




\begin{tabular}{|c|c|c|c|}
\hline \multicolumn{4}{|c|}{$\begin{array}{c}\text { Table } 4 \\
\text { The Effect of the Crisis onthe Income Diversification across Bank's Ownership } \\
\text { (Continue) }\end{array}$} \\
\hline Independent Variables & Public Bank & Foreign Bank & Private Bank \\
\hline \multirow[t]{2}{*}{ Crisis } & 0.120602 & -0.048180 & 0.066649 \\
\hline & $(0.4642)$ & 0.2559 & (0. 2251) \\
\hline \multirow[t]{2}{*}{ Constant } & -2.223967 & 0.291845 & 0. 191181 \\
\hline & $(0.0725)$ & $(0.1421)$ & $(0.379)$ \\
\hline R squared & 0.4218 & 0.3651 & 0.4823 \\
\hline \multirow[t]{2}{*}{ F statistic } & 2. $918594^{\star \star}$ & 5. 823259 & $9.550903^{* * *}$ \\
\hline & (0. 014526) & $(0.000007)$ & $(0.000000)$ \\
\hline \multirow[t]{2}{*}{ Hausman } & - & 42. $669459^{* * *}$ & 26. $624891^{* \star *}$ \\
\hline & & $(0.0000)$ & $(0.0008)$ \\
\hline Durbin Watson statistic & 2. 171339 & 1. 925548 & 2. 045213 \\
\hline $\mathrm{N}$ & 41 & 90 & 91 \\
\hline \multicolumn{4}{|l|}{$\begin{array}{l}\text { Panel } B \text { dependent variable } \\
\text { is traditional fee for service }\end{array}$} \\
\hline \multirow[t]{2}{*}{ TFS (lagged) } & -0.189867 & $0.667466^{* * *}$ & $0.48933^{* * *}$ \\
\hline & (0.1882) & $(0.0000)$ & $(0.0001)$ \\
\hline \multirow[t]{2}{*}{ Ln Asset } & -0.199866 & 0.008206 & -0.008257 \\
\hline & $(0.1711)$ & $(0.4372)$ & $(0.6285)$ \\
\hline \multirow[t]{2}{*}{ ROE } & 1. $863419^{*}$ & -0.031376 & -0.225947 \\
\hline & $(0.0975)$ & $(0.6866)$ & $(0.3458)$ \\
\hline \multirow[t]{2}{*}{ LLP Loan } & 7. 139937 & 1. 136742 & 0.466943 \\
\hline & $(0.1770)$ & $(0.0245)$ & $(0.4393)$ \\
\hline \multirow[t]{2}{*}{ Loan Asset } & $-2.142975^{\star}$ & -0.100515 & -0.104915 \\
\hline & $(0.096)$ & $(0.4730)$ & $(0.6669)$ \\
\hline \multirow[t]{2}{*}{ Cap Asset } & $0.020151^{* * *}$ & 0.001063 & -0.004433 \\
\hline & $(0.0121)$ & $(0.6166)$ & $(0.5769)$ \\
\hline \multirow[t]{2}{*}{ Year } & 0.065436 & -0.007438 & 0.013383 \\
\hline & $(0.2438)$ & $(0.3742)$ & $(0.4798)$ \\
\hline \multirow[t]{2}{*}{ Crisis } & 0.147621 & $0.063987^{* *}$ & -0.063442 \\
\hline & $(0.2216)$ & $(0.0371)$ & $(0.2563)$ \\
\hline \multirow[t]{2}{*}{ Constant } & 2. 678154 & 0.120423 & 0.264916 \\
\hline & $(0.1818)$ & $(0.4152)$ & (0. 2521) \\
\hline R squared & 0.5031 & 0.5307 & 0.4198 \\
\hline \multirow[t]{2}{*}{ F statistic } & 2. $657678^{\star *}$ & 19. $22771^{* * *}$ & 3. $889134^{* * *}$ \\
\hline & $(0.034675)$ & $(0.000000)$ & $(0.001592)$ \\
\hline \multirow[t]{2}{*}{ Hausman } & - & 34. $308043^{* * *}$ & 41. $666991^{* * *}$ \\
\hline & & $(0.0000)$ & $(0.0000)$ \\
\hline Durbin Watson statistic & 2. 204604 & 2. 103576 & 2. 135999 \\
\hline $\mathrm{N}$ & 30 & 145 & 52 \\
\hline \multicolumn{4}{|c|}{$\begin{array}{l}\text { Note: Absolute values of t-statistics are in parentheses, * **, and *** indicate significance at } 10 \%, 5 \% \text {, and } 1 \% \text { levels } \\
\text { respectively. NS: Non-traditional Stakeholder; TFS: Traditional and Fee for Service LNASSET: Log of Total assets; ROE: } \\
\text { Return on Equity; LLPLOAN:Ioan loss provisions/Total loans; LOANASSET: Loans to Total Asset; Cap_ta: Capital to } \\
\text { Total Asset; Year: Year Dummy; Crisis: Crisis Year Dummy. }\end{array}$} \\
\hline
\end{tabular}




\section{CONCLUSION}

Indonesian banking is growing rapidly and attracts various investors to participate in this sector. This paper examines the effect of the ownership and the global crisis on the income diversification of Indonesian Banks, during the period of 2005 to 2012.

The first finding of this paper is the ownership does not affects the income diversification for the Indonesian banks; both to the non-traditional stakeholder and the traditional and fee for service (non-interest) income. Though not statistically significant, the estimated coefficient is negative for the public ownership bank, while for foreign ownership banks, the direction is positive. We argue this differences is an indication for the public banks to not intensively generate their non-interest income, while the foreign banks can better optimize this source of income.

Across types of ownership, the capitalization significantly affect the non-traditional stakeholder (non-interest) income for public bank, with positive sign (second finding). For state banks, the size positively and significantly effect their traditional and fee for service income (third finding).

The fourth finding of this paper is that the credit risk positively and significantly affect the traditional and fee for service (non-interest) income of the foreign banks. In contrast, the effect of the credit risk is negative for the private banks. The fifth finding is the profitability significantly affects the traditional and fee for service (non-interest) income in private banks, with positive direction. The effect of the global crisis on non-traditional (non-interest) income is not significant, but significantly encourages the banks to generate traditional and fee for service (non-interest) income (fifth finding).

These findings support the taxonomy made by De Young and Rice (2004), since different types of income diversification has different characteristics. Anyone should avoid to generalize the income diversification. Futhermore, related to the bank supervision during crisis period, the regulators should concern more about the different effect of the crisis across types of banks, hence an ownership-specific policies should be more appropriate. 


\section{REFERENCES}

Aizenman, Joshua, Hutchison, Michael and Lothian, James. (2013). The European Sovereign Debt Crisis: Background and Perspectives, Overview of the Special Issue. Journal of International Money and Finance, 34, pp 1-5.

Acharya, Viral, V. , Hasan, Iftekhar and Saunders, Anthony. (2006). Should Banks be Diversified? Evidence from Individual Banks Loan Portfolios. The Journal of Business, 79, pp 13551412.

Beck, Thorsten, Demirgüç-Kunt, Asli, Maksimovic, Vojislav. (2004). Bank Competition and Access to Finance: International Evidence. Journal of Money, Credit, and Banking, 36, 627-648.

Berger, Allen, N. , Hasan, Iftekhar and Zhou, Mingming. (2010). The Effect of Focus Versus Diversification on Bank Performance: Evidence from Chinese Banks. Journal of Banking and Finance, 34(7), pp 1417-1435.

Bonin, John, P. , Hasan, Iftekhar, Wachtel, Paul. (2005). Privatization Matters: Bank Efficiency in Transitional Countries. Journal of Banking and Finance, 29 (8-9), pp 2155-2178.

Blum, Jurg. (1999). Do Capital Adequacy Requirements Reduce Risks in Banking?. Journal of Banking \& Finance, 23, pp 755-771.

Cetorelli, Nicola and Goldberg, Linda, S. (2011). Global Banks and International Shock Transmission: Evidence from the Crisis. IMF Economic Review, 59 (1), pp 41-76.

Cornett, Marcia M. ,Guo, Lin, Khaksari, Shahriar, and Tehranian, Hassan, (2010). The Impact of State Ownership on Performance Differences in Privately-owned Versus State-owned Banks: An International Comparison. Journal of Financial Intermediation, 19(1), pp 74-94.

Demirguc-Kunt, Asli and Huizinga, Harry. (2010). Bank Activity and Funding Strategies: The Impact on Risk and Returns. Journal of Financial Economics, 98, pp 626-650.

De Young, Robert and Rice, Tara. (2004). Non-interest Income and Financial Performance at US Commercial Banks. Financial Review, 39, pp 101-127.

De Young, Robert and Torna, Gokhan. (2013). Nontraditional Banking Activities and Banks Failures during the Financial Crisis. Journal of Financial Intermediation, 22(3), pp 397-421.

Dewenter, Kathryn, L and Malatesta, Paul, H. (2001). State-owned and Privately-owned Firms: an Empirical Analysis of Profitability, Leverage, and Labor Intensity. American Economic Review, 91, pp 320-334.

Hadad, Muliaman, D., Santoso, Wimboh, Besar, Dwityapoetra, S. , Purwanti, Wini, and Satria, Ricki. (2004). Fungsi Intermediasi Bank Asing Dalam Mendorong Pemulihan Sektor Riil di Indonesia. Bank Indonesia Research Paper No. 6/1 8, 2004. 
Hart, Oliver., Shleifer, Andrei and Vishny, Robert, W. (1997). The proper scope of government: Theory and An Application to Prisons. Quarterly Journal of Economics, 112, pp 11271161.

Hidayat, Wahyu, Y. , Kakinata, Makoto and Miyamoto, Hiroaki. (2012). Bank Risk and Noninterest Income Activities in the Indonesian banking Industry" International University of Japan. Economics and Management Series working paper EMS, 03, 2012.

Iannotta, Giuliano ,Nocera, Giacomo and Sironi, Andrea. (2007). Ownership Structure, Risk and Performance in the European Banking Industry. Journal of Banking and Finance, 31(7), pp 2127-2149.

Indonesian Banking Statistics. (2004). monthly report, January.

Indonesian Banking Statistics. (2012). monthly report, December.

Leaven, Luc, and Valencia, Fabian. (2012). Systemic Crises Banking Database: An Update. IMF Working Paper no. WP/12/163, 2012.

Jeon, Yongil, and Miller, Stephen, M. (2005). Performance of Domestic and Foreign Banks: The Case of Korea and The Asian Financial Crisis. Global Economic Review, 34(2), pp. 145165.

Longstaff, Francis, A. (2010). The Subprime Credit Crisis and Contagion in Financial Market. Journal of Financial Economics, 97, pp. 436-450.

Nickell, Stephen. (1981). Biases in Dynamic Model With Fixed Effect. Econometrica, 49(6), pp. 1417-1426.

Pennathur, Anita, K. ,Subrahmanyam, Vijaya and Vishwasrao, Sharmila. (2012). Income Diversification and Risk, Does Ownership Matters; An Empirical Examination on Indian Banks. Journal of Banking and Finance, 36, pp 2203-2215.

Sato, Yuri. (2005). Bank Restructuring and Financial Institution Reform in Indonesia. The Developing Economies, XLIII-1, pp. 91-120.

Shleifer, Andrei and Vishny, Robert, W. (1997). A survey of Corporate Governance. Journal of Finance, 52, pp 737-783.

Sufian, Fadzlan and Habibullah, Muzafar, S. (2010). Assessing the Impact of Financial Crisis on Bank Performance: Empirical Evidence from Indonesia. ASEAN Economic Bulletin, 27(3), pp 245-262.

Vallascas, Francesco, Crespi, Fabrizio and Hagendorff, Jens. (2012). Income Diversification and Bank Performance During the Financial Crisis. Retrieved December 18, 2012). Available at SSRN: http://ssrn. com/abstract=1793232 or http://dx. doi. org/10. 2139/ssrn.1793232. 